\title{
The Vanishing Sector. A Case Study on Private Higher Education Institutions in Poland
}

Marcin Geryk (D)

Jagiellonian University

\section{Introduction}

The main aim of this paper is to introduce the publication of a research-based monograph on private higher education institutions in Poland. A brief summary of the results should give the reader a general idea of the current state and the future problems that this sector is exposed to. The research project in the period of 2015-2019 focused on private university leaders and their opinions about what school management will look like in the near future and what the perspectives for growth in the private sector of higher education in Poland are (if any).

\section{The Current State of the Private Higher Education Sector}

The system of higher education in Poland has undergone intensive change for almost three decades. This resulted not only from the socio-economic transformations initiated at the turn of the 1980s and 1990s, when the political and economic system of the country changed dramatically, but also from changes of a global nature and the dynamic development of science and modern technologies, which affected the availability of scientific achievements on a global scale.

The Polish higher education system is very diverse, both in terms of its quality and quantity. It consists of both public and private universities, the number of which is particularly large compared to the number of institutions of this type in other countries of the world ${ }^{1}$.

1 M. Kwiek, Uniwersytet w dobie przemian, Wydawnictwo Naukowe PWN, Warszawa 2015. 
To better illustrate the scale of these changes, it is worth mentioning that in the academic year of 1990-1991, only 403,800 people studied in Poland, rising to $1,926,100$ in 2004-2005 and reaching a peak of 1,937,400 in 2007-2008. From that moment, the number of students has gradually dropped, and it can be assumed that the Polish higher education system has exhausted its basic possibilities of quantitative growth. The number of students, as of November 30th 2017, amounted to $1,291,870$, so a decrease of more than 33 percent in the number of students was recorded (GUS) ${ }^{2}$.

Demography specialists expect that the number of students reached in 2007-2008 will never be exceeded in future. The greatest drop in the number of students will be visible in the Śląskie, Małopolskie, Podkarpackie, Podlasie, Lubuskie, Wielkopolskie, Zachodniopomorskie, Dolnośląskie, Opolskie and Warmińsko-Mazurskie Voivodeships. A more promising situation will be noticed in Warsaw, Cracow and Wroclaw. These cities have the strongest academic background and attract immigrants and students from other areas ${ }^{3}$.

Such a dynamic drop in the number of students is comparable to the economic bubble that is about to burst, which will lead to increasingly serious financial turmoil because of the heavy dependence of private schools on tuition fees ${ }^{4}$. Systems of higher education in other countries also face similar threats. For example, nearly half of American colleges and universities no longer generate enough tuition revenue that equals or exceeds the rate of inflation ${ }^{5}$.

The challenges that higher education is confronted with are not unique to Poland. The whole system of tertiary education in Europe is outperformed by those of the US, Canada, Japan, Korea and Australia.

The complexity of the problems involving the funding of the system are common in the whole of Europe, not only in Poland. The situation has been changing for the last two to three decades and is connected with a change from an elite

2 GUS [Polish Central Statistical Office], Szkolnictwo wyższe w roku akademickim 2017/2018 (dane wstępne), https://stat.gov.pl/obszary-tematyczne/edukacja/edukacja/szkolnictwo -wyzsze-w-roku-akademickim-20172018-dane-wstepne,8,5.html (accessed: 30.01.2020).

3 M. Geryk, Zmiany w systemie szkolnictwa wyższego oraz ich wpływ na zarządzanie uczelniami w Polsce. Bilans 25-lecia, [in:] S.H. Zaręba, P. Komorowski, M. Zarzecki (eds), 25 lat samorzqdności w Polsce - bilans decentralizacji władzy i zmiany gospodarczej, Kontrast, Warszawa 2016, pp. 205-224.

4 J.S. Shaw, What Will Colleges Do When the Bubble Bursts?, "Academic Questions" 2011, no. 24, pp. 438-448.

5 M. Toner, The Highly Endangered Higher Education Business Model (and How to Fix It), American Council on Education, summer 2015. 
to mass model of higher education, with easy access to higher education institutions for those who apply6.

The system of private education in its current state is highly dependent on the demand for the services offered. This private component of the higher education system plays only a supportive role to the mainstream one, i.e. state universities and other higher education institutions. The demographic changes in developed countries are one of the most significant factors that not only reduce the demand for educational services in the private sector but also highly influence the market and the financial situation of those institutions.

The dependence of the private sector on demographics, and its interdependence with the public sector, in the case of Poland, is clearly visible. As Kwiek writes, the system of higher education in Poland is an example of "a dual or mixed publicprivate system in the expansion period of 1990-2005, to a deprivatizing system in which both private and state funding are playing a decreasing role (2006-2016, and beyond)"7. The same author predicts that in the forthcoming years, the private sector will undergo a steady contraction, leaving the market space for public universities and other institutions with public funding. This is expected to happen after 2025 .

\section{The Sector in the Research Project}

Higher education is expanding worldwide in parallel with global economic and demographic growth. With the increasing demand for education at this level, a number of new higher education institutions (HEIs) have been established. The political and economic changes in Central and Eastern Europe paved the way for this rapid growth, with more than 300 HEIs established in Poland alone.

The main conditions for the expansion included the high demand for places, which significantly exceeded the supply, together with the accompanying changes in legal regulations. The result was the creation of a completely new sector in the Polish economy: private higher education institutions, also known as "non-public high schools" focused on tertiary education.

The private HEI sector in Poland, during its peak in the mid-2000s, exceeded two million students at undergraduate and graduate levels. The explosion of the development of new schools was present in all parts of the country, but the majority

6 G. Grotkowska, Tertiary "Education boom in EU countries: key to enhancing competitiveness or a waste of resources?", "Studia Ekonomiczne. Zeszyty Naukowe Uniwersytetu Ekonomicznego w Katowicach" 2016, no. 271, pp. 66-76.

7 M. Kwiek, Changing Public-Private Dynamics in Polish Higher Education, "International Higher Education" 2016, no. 18, p. 18. 
were based in Warsaw, the capital of Poland. From that moment, the sector was exposed to visible changes, caused not only by demographics, but also by new legal regulations which almost openly favoured public universities.

The paper presents a brief summary of a half-decade research project on the development of perspectives of private higher education institutions in Poland covering the years 2015-2019. The research focuses on the main problems that managers are faced with, mostly those involving the perspectives of the development of the sector, management processes and the current management in light of the legal regulations.

The research was conducted in two parts: the first in 2015, and the second later, to allow a comparison of the data collated from the respondents, i.e. school managers, rectors, deans and/or senior lecturers. The results are presented in a descriptive manner with a presentation of the background of the leading existing institutions.

The aim of the paper is to present the changes to this sector of the higher education market that, after its impressive development and existence for more than two decades, is now on the verge of collapse. The challenges that these institutions' managers are faced with are completely new. Few representatives see their future as one that brings positive challenges. The majority, recognize that the Polish private school sector is in its declining years.

The conclusion of the research has brought some interesting findings, such as the fact that an increasing number of the institutions aim to attract international students and offer classes in English as well as a commitment to monitor the placement rate of alumni as a way to provide a programme that maximizes their usefulness in the labour market.

\section{Research. Announcement of a monograph by Marcin Geryk: The Vanishing Sector. A Case Study on Private Higher Education Institutions from Poland}

The proposed work by Marcin Geryk PhD, professor at the Jagiellonian University and the Gdańsk Health College is an in-depth comparative analysis of non-public higher education in Poland, encompassing a wide range of components to create a complementary picture of this education sector. It is not limited to a simple compilation of data with a commentary; the idea of the publication aims to precisely present the output data in order to synthesize a comprehensive picture of two 
important years for higher education in Poland in the second decade of the 21st century. The years in question are 2015 and 2018, when successive reforms were introduced within the Law on Higher Education. The reaction to the changes reflected in the objective numerical and percentage data underlies the formulation of the title thesis, i.e. "the vanishing sector" that the author refers to.

The publication was logically divided into content segments, allowing for a better overview of the individual threads of the analysis, which in turn made it possible to summarize the synthesis and draw reliable conclusions. The paper adopted the format of a classic monograph, and it consists of seven autonomous parts of the main text (an introduction, five chapters and conclusions). The book is supplemented by a summary preceding the main text, a list of figures and illustrations, and an appendix. In the latter, the universities taking part in the survey in 2015 and in 2018 were listed in a tabular system, because a different number of institutions took part in it - 103 and 52, respectively. Before discussing the contents of the individual components of the main text, it is worth focusing on the second additional element - a list of illustrations - because its reading allows a better understanding of the idea and the scope of the work undertaken. The book contains a total of 114 drawings/ charts and tables illustrating over 50 individual categories/parameters, according to which the axis of the comparative statement between 2015 and 2018 was determined in the context of the current state, the recent past and the foreseeable future. In most cases, these are illustrations of the same issues or answers to the same questions asked in 2015 and 2018.

There are cases when a change of circumstances provokes different questions, even though they concern the same problem, such as the issue of provisions contained in the amendment to the Law on Higher Education from October 2014 and the so-called Act 2.0, whose individual elements have been gradually introduced since 2018. Finally, a few questions (regarding the measures taken to attract foreign students (2015), the use of investment credit and the number of majors and the year of establishment of the university (2018), for example) were only asked in 2015 or 2018. This allows one to capture the shift of an element's weight from significant to negligible, or one which was not included in previous studies but subsequently became important, or research that captures both analysed years.

Finally, in individual cases, the discussion of a specific issue is illustrated by two descriptions for 2015 and 2018, with one of the illustrations missing (e.g., the question: "Did you implement an IT system or special software to improve university management?"). This procedure serves to reduce unnecessary information, because the description shows that the differences in percentages between the studies of 2015 and 2018 are minimal or the condition did not change at all. Undoubtedly, the inclusion of rich illustrative material and the addition to it of precise 
descriptions of each visualization contributes to a better reception of all the information that can be seen in general and with respect to the smallest components differentiating (or not) the description.

The first part of the main text is the introduction, where the substrate for the overall analysis is indicated, i.e. the results of a survey of a representative group of Polish non-public universities, conducted in 2015 using the CAPI (computer assisted personal interview) technique, and in 2018 - using the CAPI and CAWI (computer assisted web interview) techniques. The issues raised during the study concerned, among others, an assessment of the operating conditions and development perspectives of non-public universities, the management process and the day-to-day operation of the university - the sources of financing and costs, and the characteristics of scientific and didactic and administrative employees. In both cases, the questionnaires consisted of five parts concerning the same issues (part four - opinions on the latest amendment to the "Law on Higher Education" Act - for obvious reasons in 2015 and 2018 related to different amendments).

The first chapter - Characteristics of the Respondents - contains an exhaustive description of the people and institutions represented by them. Profiles of the respondents are selected in a methodical way, among which rectors of the mentioned universities constitute the majority (68\%). In terms of academic degrees and titles, nearly $50 \%$ of the respondents have doctorates and over $25 \%$ are university and titular professors. The credibility of the data on the one hand and the scale of research on the other is evidenced by the fact that the respondents represent universities which were attended by a total of 160,000 students at that time (approximately half of all students enrolled in the non-public higher education sector in Poland). The highest possible objectivity of the base materials for the analysis was of importance: the number of higher education institutions established before and after 2000 is exactly equal, i.e. those already having a generational tradition versus those regarded as "young"; the share of universities by the criterion of size is also balanced: over a third are "small" institutions (up to two faculties), about half are medium-sized (between three to four and five to ten faculties - a quarter of the total), and one in ten is a "big" facility (over ten faculties). It should be noted, however, that currently one to two-faculty universities now constitute $40 \%$ of the current total. The research revealed a clear tendency to an interdependence between the number of courses and the profile of studies: the widest offer is usually presented by medical and technical universities the narrowest by institutions with humanistic and social specializations. In the private sector, universities with a social sciences profile are invariably dominant, while those offering courses in the field of art, science and natural sciences are the least numerous. However, at the beginning of the analysis, data appeared 
constituting a strong argument for the truth of the thesis of "the vanishing sector": only 14\% of those surveyed were created after 2005.

The second chapter - Business Conditions and Development Perspectives of the Non-public University Sector - refers to the topic of the shrinking of this area of academic activity, raising issues such as the changing number of students willing to study (as the main factor affecting the changes and related to the falling demographics); the possibility of and application for EU funds and expanding the educational offer; the possibility of applying for EU funds from the National Science Centre and the National Centre for Research and Development; and the deterioration in the profitability of higher education services. The factor significantly affecting the number of students in the private sector was the deepening competitiveness imbalance in relation to public universities (not to mention the increasingly fierce competition within this sector) and unfavourable legal regulations. In the period between 2015 and 2018, a group of respondents declaring a fall of in private higher education resulting from economic change (a double increase from 4 to $8 \%$ ) became clearly visible.

The negative demographic impact, where the decreasing number of candidates is the main factor, is also confirmed by the forecast of the number of students for the next decade: four in ten respondents stated that the number of students would decrease in the next ten years. A similar percentage, $44 \%$, said that this number would stabilize at the current level. Only $8 \%$ of the respondents predicted an increase in the number of students and the same percentage could not provide any prediction. The perception of the current condition of this sector is quite similar: $42 \%$ of the respondents pointed to its maturity, $29 \%$ said that the sector is in a development phase, while $27 \%$ of the respondents thought that the phase is in decline. This belief about the "maturity" of non-public higher education and the gradual decrease of the recruitment pool are further arguments for the title's claim that this is a "vanishing sector".

It is quite significant that the reasons for the upcoming breakdown of this segment of education were seen in terms of internal problems: 60\% indicated the high operating costs of providing high quality education and the competition from public universities, $25 \%$ talked about the lack, or the small scale, of investment in infrastructure, and over $20 \%$ of the respondents were of the opinion that the competition from non-public universities could be a factor in the decrease in the number of universities; only a few respondents mentioned, for example, poor state policy regarding the functioning of the non-public university sector or the decisive influence of the negative demographic factor.

The third chapter - The Current Functioning and the Management Process of a Non-public University - focuses on the everyday life of these institutions, i.e. 
the functioning and management process of a non-public university in the existing macroeconomic conditions. The opinion that the management of the a university in the existing macroeconomic conditions is difficult remained at an unchanged level (almost 90\%), while in smaller institutions, a significant percentage (as high as 16\%) is of a different opinion. This difficulty consists mainly of financial management and legal conditions (including lack of legal stability, the large number of regulations and the constantly changing regulations regarding the non-public university sector) as well as the decreasing number of students, bureaucratic and administrative barriers, high competition, and high number of personnel and fixed costs. These factors are also indicated as a serious threat to the further functioning of the sector in question and clearly support the thesis of the eventuality of its "demise".

The black scenario regarding the future of non-public universities dominates despite the belief that in terms of adaptability to market conditions, accessibility to students, marketing efficiency and financial management, no over-employment and a sense of responsibility to students and others, these institutions are much better organized than public universities. Representatives of non-public universities indicated the difficulties they face in their institutions, including three basic ones: competition from public universities (70\%), excess of legal regulations concerning the functioning of non-public universities (54\%) and the unfavourable image of non-public universities in the eyes of the public and in the media, i.e. the lack of trust in non-public universities (40\%).

As regards the development of universities, and their current status and plans, there is a summary of all current activities of the discussed universities with the prospect of development for the future. The following activities dominate: orientation towards brand building and standard marketing activities; activities aimed at attracting domestic students; creation of a new faculty or branch; systematic actions aimed at acquiring EU funds; accreditation up to the second level; capital and infrastructure investments. With regard to the implementation of the planned activities over the next five years compared to the activities that took place during the previous five years, the largest change is that more universities want to obtain international accreditation, i.e. EQUIS (European Quality Improvement System), AACSB (Association to Advance Collegiate Schools of Business), AMBA (Association of MBAs), and CEEMAN (Central and East European Management Development Association) - an increase from $10 \%$ to $31 \%$. The next largest change is activity related to obtaining specifically environmental accreditation (an increase from 27\% to 38\%). Other activities declared are attempts to acquire foreign students, and monitoring the so-called placement rate, or the ratio of graduates employed (67\% of universities have been monitoring this over the past five years). The outsourcing of didactic services will be run at a similar level. An antidote to the shrinking sector is to adjust educational courses to the needs 
of the labour market, to introduce "practical" courses or training, to increase cooperation with employers, and to conduct research and development activities. These plans will support the training of employees, raising their qualifications and obtaining higher academic titles. Universities want to motivate employees to further develop, and plan to hire new employees, while some have mentioned the rotation or rejuvenation of staff.

As regards the legal conditions for the functioning of a university, there is an analysis of the block of questions regarding the management of private higher education in the current legislative environment, with particular emphasis on the impact of the latest amendment to the Law on Higher Education. A rather pessimistic picture emerges from the latest surveys: half of the respondents assessed university management in the current legal conditions as rather difficult, while $37 \%$ found it difficult. The rates for answers "rather easy" and "easy" were the same, i.e. $6 \%$ in each category. People who thought that university management was difficult pointed to the lack of financial support from outside sources and fierce competition, which was already evident in previous responses. The regulations restricting the possibility of employing research and teaching staff at many universities at the same time are assessed as poor. As many as $59 \%$ believe that changes in the law will affect the sector badly in the near term. The situation may be saved by changing the rules of financing the university, as well as employing staff, reducing regulatory and bureaucratic burdens, stabilizing legal regulations, having the same treatment as public universities, levelling funding, and abolishing certain mandatory practices. As many as $65 \%$ believe that Act 2.0 will not bring positive changes. Conclusions synthetically include the above arguments, adding as proof of the veracity of the conclusion that from 2015 to 2018 higher non-public schools were gradually being closed. In 2015 there were 291 non-public universities and by the end of 2018 there were 249 (42 fewer). This process will gradually increase unless a number of activities are implemented on the part of those responsible for the condition from the Ministry of Higher Education and Science.

\section{Conclusions}

This brief presentation of the data obtained during a cross-sectional study carried out in 2015-2019 shows the challenges that private universities in Poland are exposed to. The demographic turmoil is resulting in shrinking funds and a diminishing number of students and is a threat to the existence to some institutions, mostly small ones and those with a lower number of programmes and students enrolled. 


\section{References}

Geryk M., Zmiany w systemie szkolnictwa wyższego oraz ich wpływ na zarzqdzanie uczelniami w Polsce. Bilans 25-lecia, [in:] S.H. Zaręba, P. Komorowski, M. Zarzecki (eds), 25 lat samorzqdności w Polsce - bilans decentralizacji władzy i zmiany gospodarczej, Kontrast, Warszawa 2016, pp. 205-224.

Grotkowska G., Tertiary "Education boom in EU countries: key to enhancing competitiveness or a waste of resources?", "Studia Ekonomiczne. Zeszyty Naukowe Uniwersytetu Ekonomicznego w Katowicach" 2016, no. 271, pp. 66-76.

GUS [Polish Central Statistical Office], Szkolnictwo wyższe w roku akademickim 2017/2018 (dane wstępne), https://stat.gov.pl/obszary-tematyczne/edukacja/edukacja/szkolnictwo-wyzsze -w-roku-akademickim-20172018-dane-wstepne,8,5.html (accessed: 30.01.2020).

Kwiek M., Changing Public-Private Dynamics in Polish Higher Education, "International Higher Education" 2016, no. 18, pp. 18-20.

Kwiek M., Uniwersytet w dobie przemian, Wydawnictwo Naukowe PWN, Warszawa 2015.

Shaw J.S., What Will Colleges Do When the Bubble Bursts?, "Academic Questions" 2011, no. 24, pp. 438-448.

Toner M., The Highly Endangered Higher Education Business Model (and How to Fix It), American Council on Education, summer 2015.

\section{Abstract}

The main aim of this paper is to introduce the publication of a research-based monograph on private higher education institutions in Poland. A brief presentation of data obtained during a crosssectional study carried out in 2015-2019 shows the challenges that private universities in Poland face. Demographic turmoil is resulting in shrinking funds, and the diminishing number of students is a threat to the existence of some institutions, mostly those which are smaller ones or with a lower number of programmes and students enrolled.

Keywords: private higher education, students, demographic changes, university management 